Paideusis

\title{
"Civic Virtues and Public Schooling" (Patricia White)
}

\section{Paul O'Leary}

Volume 11, Number 2, 1998

URI: https://id.erudit.org/iderudit/1073107ar

DOI: https://doi.org/10.7202/1073107ar

See table of contents

Publisher(s)

Canadian Philosophy of Education Society

\section{ISSN}

0838-4517 (print)

1916-0348 (digital)

Explore this journal

\section{Cite this review}

O'Leary, P. (1998). Review of ["Civic Virtues and Public Schooling" (Patricia White)]. Paideusis, 11(2), 77-78. https://doi.org/10.7202/1073107ar viewed online.

https://apropos.erudit.org/en/users/policy-on-use/ 
judgment-making ability or will come to have it without much assistance by the end of their formal preparation. But we should not just assume new teachers will "find" or just develop their good judgment-making abilities. As Hostetler argues, much of good judgment-making involves seeing things in particular ways. We should ask ourselves, therefore, whether what we do in our teacher education programmes is likely to help new teachers respond appropriately to situations and to move forward.

Hostetler's valuable service, then, is to convince readers that ethical judgment-making is part of being a good critical thinker and a good teacher. He is correct, $I$ think, in saying that very little overt attention is paid by teacher education programmes to ethical judgment in teaching although in faculties of education across the country, we do place emphases on ethics-related policies in different subject areas (such as integration of special needs students into classrooms, priorities for funding school programmes, and so on). We also expect student teachers not only to be aware of but to reach ideal standards of performance and personal interaction.

\section{Reviewed by Sandra Bruneau, University of British Columbia}

\section{Patricia White. Civic Virtues and Public Schooling. New York: Teachers \\ College Press, 1996.}

In the high school I attended, every student was required to take one, but only one civics course. The brevity of the school's attention to matters of civic education as well as its indifference to the qualifications of those who taught it-in my school civics was taught by the guidance counsellor-no doubt reflected the idea that the formation of citizens was a straightforward matter of providing information about government coupled with conventional moralizing. It is one merit of Patricia White's new book that it avoids any kind of moralizing. It is yet another that the approach to civic education does not place emphasis on learning about the machinery of government, but rather considers how the school may contribute to the formation of those dispositions of character which are necessary to the maintenance and flourishing of the values characteristic of a democratic polity. In taking this approach, White hopes that we will no longer view civic education as unproblematic and, thus, will allow teachers time and opportunity to reflect on the ethical complexities which arise in connection with a virtue based civic education.

Surprisingly, her treatment of the civic virtues does not include qualities such as justice and tolerance, but rather deals with items such as hope, confidence, self-respect and self-esteem, friendship, trust, honesty, and decency. Her reason for this unusual selection is that these latter qualities have, undeservedly, received far less attention in the literature than have justice and tolerance. Yet, she does devote a chapter to courage, which, like the virtue of justice, has been the subject of a substantial literature. Also absent is any treatment of practical wisdom (phronesis) which, it can be argued, is at the heart of any education which seeks to foster the virtues. Indeed, much of the ethical complexity which White shows to be part of civic life and civic education, seems to call out for some explicit treatment of how the fostering of practical wisdom might be achieved. 
Except for chapters 1 and 9, each chapter deals with one of the virtues to be found on White's list. Since these chapters have made earlier appearances in several journals at various times, each can be read independently of the others and no particular reading order is required. In the course of examining each of these virtues, White utilizes any number of examples from literature which unfailingly illuminate what can be, for many, dauntingly abstract territory. There are however, several questions which her treatment of the civic virtues suggests and I should like, however briefly, to consider some of these.

The first concern arises in connection with the possible differences between those virtues which are civic in nature and those which are moral. The latter, being those qualities of character which make one a good human being, may be quite different from those qualities which make a citizen of a particular polity a good citizen. How moral and civic virtues are related depends I believe, on a certain conception of citizenship and its relation to what constitutes a satisfying life for human beings. Although White's book is supposed to be about the civic virtues, there is, unfortunately, no consideration given to the issue of citizenship and its relation to the moral virtues. Indeed, in her chapter on friendship, a discussion of civic friendship is deliberately avoided, thus leaving an important point of connection between civic and ethical life unexplored.

The second matter I wish to raise concerns White's conception of virtue. Although "virtue" has something of an old fashioned ring to it suggesting nothing more than a general approbation, ancient writers as well as those engaged in the more recent turn towards "virtue ethics" have been concerned with considering the virtues as dispositions rather than habits or skills. This is a view which White also shares. Yet, when we consider the list of civic virtues proposed by White, while honesty and courage easily fit the disposition model, friendship does not. Indeed, friendship, which is not the same as friendliness, is a relationship rather than a disposition. Moreover, self-esteem and self-respect seem unlike desirable dispositions of character but more like affective states whose desirability is based upon and relative to other conditions.

My concern in all this, is not the fussy linguistic one of how the word "virtue" is to be used, but is rather about the absence in White's book of any sustained enquiry into the sort of "thing" a virtue is. Is a virtue of character a disposition, a skill, a habit, a relationship, or an affective state? Is there a significant difference between relative and non-relative virtues? And finally, what are the differences between civic and moral virtues? Our understanding of civic education as a matter of fostering the civic virtues depends upon some kind of reasoned response to these questions.

While I obviously have some scepticism about the contribution White's book makes towards our understanding of the nature of the civic virtues and the role of the school in fostering them, it does not extend to her treatment of some of her topics which have indeed been neglected in the educational literature. So even if self-esteem and self-respect are not virtues, the distinction she draws between them as well as their relation to different bases are well worth any teacher's attention. My scepticism is, therefore, limited.

Reviewed by Paul O'Leary, The University of Western Ontario 